\title{
Multiple ways for the same destination: bone regeneration
}

\author{
Seong-Gon Kim(1)
}

\begin{abstract}
The regeneration of the bone is a challenging topic for maxillofacial plastic and reconstructive surgeons. For successful bone regeneration, timely providing of essential components is prerequisite. They are cellular components (osteoblasts, osteoclasts, and immune cells), extracellular matrix, and inorganic components (calcium and phosphate). Any deficient component can be provided from outside as a graft. Accordingly, there are many ways for successful bone regeneration. Selection of appropriate methods in an individualized situation is important.
\end{abstract}

Keywords: Bone graft, Bone morphogenic protein-2, Osteoinduction, Osteoconduction, Hydroxyapatite

\section{Background}

Bone is the largest depot for calcium and phosphate. It is mainly responsible for the maintenance of blood calcium levels. The broken balance in blood calcium level is fatal. Bone remodeling is a coupled process between bone formation and resorption [1]. Physiologic bone remodeling is a continuous process. Broken balance during bone remodeling may result in either osteoporosis or osteopetrosis. Different types of hormones are involved in the bone remodeling process. Blood calcium levels can be elevated by bone resorption and decreased by excretion from the kidney [2].

In case of bone formation, inorganic components and organic components are required. Calcium and phosphate are essential inorganic components for bone formation [3]. Collagen is the main protein for the bone matrix. Bone formation is solely done by osteoblasts. Though osteoclast is mainly the responsible cell for bone resorption, the local acidic environment also accelerates decalcification and proteolysis of the bone matrix. Therefore, bone resorption is a less expensive process compared to bone formation in terms of energy requirement. Aging is an imbalance of energy consumption.

Correspondence: kimsg@gwnu.ac.kr

Department of Oral and Maxillofacial Surgery, College of Dentistry,

Gangneung-Wonju National University, Gangneung 25457, Republic of Korea
Bone loss is much higher than bone gain during aging. Therefore, osteoporosis is a kind of aging process [4].

Except for physiological regulation of bone remodeling, some situations asked for active new bone formation. For example, fracture is a trauma in the bone. The bony defect between the fractured ends asks for active bone formation for repair. Surgical defect after treatment of bony lesion also requires active new bone formation [5]. If the size of the defect is small, the defect will be healed naturally without graft. In case of critical-sized defect, complete healing is not expected without a proper bone graft. Autogenous bone is usually taken in the operative theater and grafted immediately after being taken from the donor site. Cellular components in the autogenous bone are still alive for a couple of hours. Organic and inorganic fractions of bone are also intact. As it is autogenous, there is no immune reaction. Accordingly, autogenous bone graft has been considered as "gold standard" [1]. However, its amount is limited. In addition, donor site morbidity is another concern.

Several types of bone graft materials have been developed and available in the market. They have been classified as allograft, xenograft, and alloplast $[1,6]$. This classification is originated from the source of the graft. It is not associated with the regenerative process. In addition, some osteoinductive materials such as bone morphogenic protein-2 (BMP-2) and platelet-derived growth factor (PDGF) are not included in this classification. Bone healing is also a staged 
process from acute inflammation to remodeling [6]. Different types of cells and resources are required in each step. Systemic condition of the patients may not be favorable for a smooth transition of each step. In that case, required graft materials should be tailored to each patient's condition.

Unlike physiological remodeling, many immune cells such as macrophages are important cells for orchestrating the regenerative process [7]. However, it has been ignored largely. Immune cells are the main source for the production of osteoinductive factors. Therefore, bone regeneration should be controlled step by step. Calcium and phosphate should be supplied on demand. Matrix protein should be constructed with calcium phosphate deposition by osteoblasts. Angiogenesis is a prerequisite for the timely supply of amino acid and inorganic components to the bony defect. Macrophages should secrete osteoinductive factors such as BMP-2 for awakening resting osteoblasts. Bone grafts can help some processes among them. They may occupy the space to be filled with new bone, temporarily. In this case, the bone graft should allow creeping substitution. Otherwise, the graft may release osteoinductive factors and activate resting osteoblasts. Any new bone graft also should consider these processes (Fig. 1).

\section{Main text}

\section{Calcium-based material}

As bone is composed of calcium, calcium-based bone graft materials have been developed. If the graft is not autogenous, foreign proteins in the bone may cause immune reactions [8]. As foreign proteins are considered as an immunogen, these ingredients may induce severe inflammation. To avoid any unwanted immune response, deproteinization is an important step for processing animal or human-originated bone as a bone graft [9]. If bone matrix proteins are removed from the bone, only inorganic components will remain. Some synthetic materials such as hydroxyapatite (HA) or $\beta$-tricalcium phosphate $(\beta-\mathrm{TCP})$ are bone grafts as calcium-based material (Fig. 2).

By experience, surgeons know a certain level of new bone formation is observed after grafting these materials. The mechanism of new bone formation in this type of material is still under investigation. Among them, calcium-based material increases local calcium concentration [10]. This situation is similar to bone resorption during physiological bone remodeling. When bone resorption is detected, osteoblasts will be activated. Immature bone is formed by osteoblasts. Subsequently, osteoblast-osteoclast coupled reaction will mature the bone as lamella bone [11].

This scenario is largely dependent on the degradation velocity of the graft. If grafts degrade too fast, local calcium concentration is exceeded the required range of calcium for bone regeneration. Too high calcium is toxic to many types of cells [12]. If the graft is not degraded, then released calcium will be absent. Both cases are improper for bone regeneration. Thus, the performance of these grafts is dependent on their degradation velocity. HA is known to be a slowly degraded material [13]. However, $\beta$-TCP is a fast degrading material. Accordingly, many types of natural bone are a combination of HA/ $\beta$-TCP and synthetic bone graft also mimics them [14].

\section{Scaffold}

The component for improving bone matrix protein production is mainly focused on accelerating the production

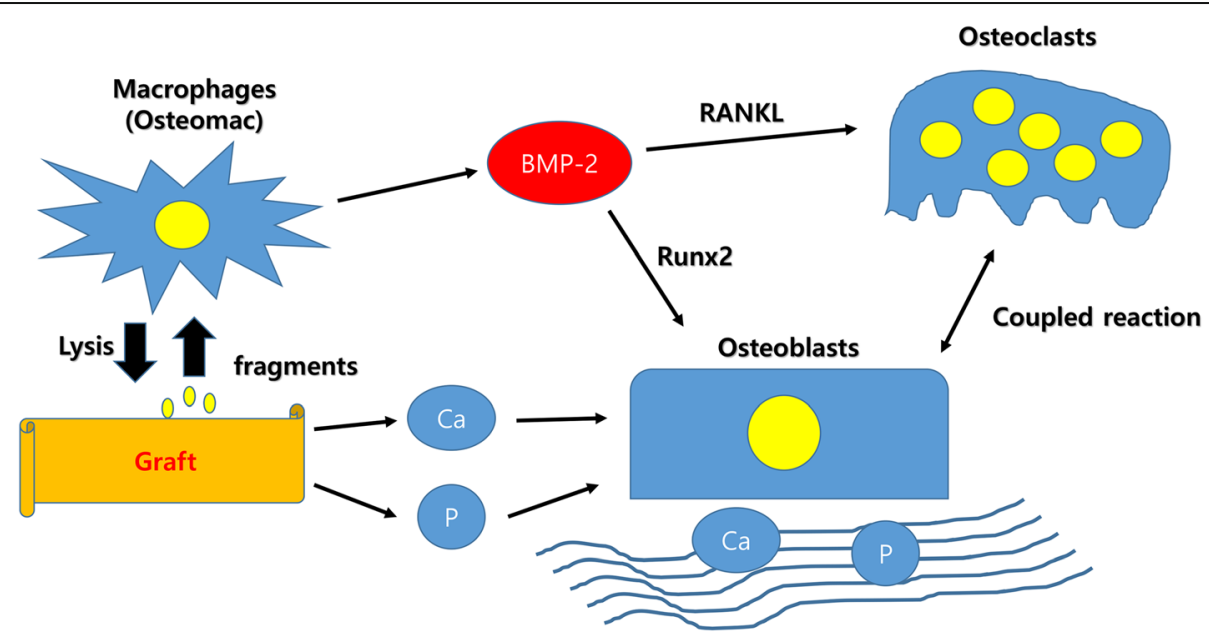

Fig. 1 Schematic drawings of the bone regeneration process after grafting. As degrading graft by macrophages, degraded fragments may influence the macrophage. Some fragments stimulate macrophages to produce bone morphogenic protein-2 (BMP-2). It activates both osteoblast and osteoclast. Runx2, runt-related transcription factor-2; RANKL, receptor activator of nuclear factor kappa-B ligand 

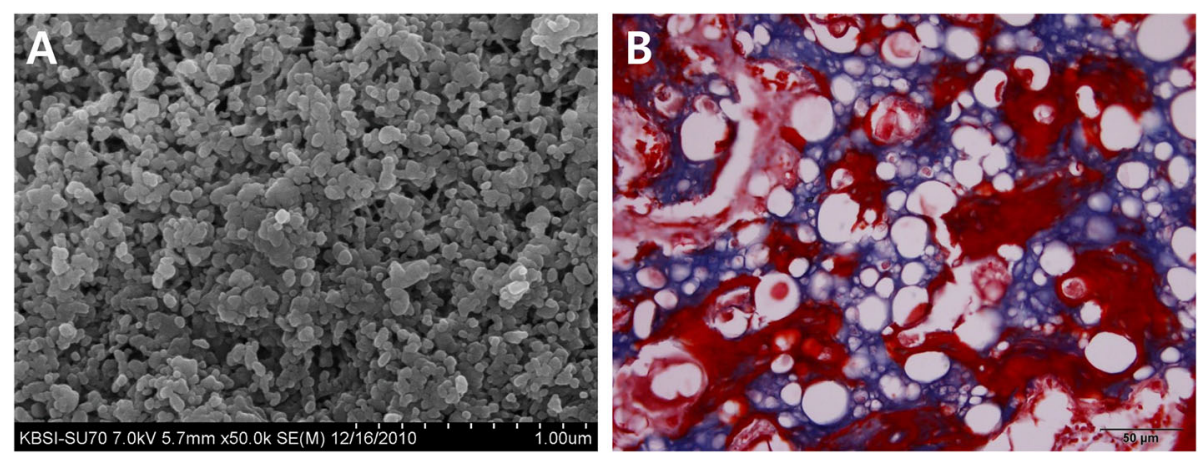

Fig. 2 Hydroxyapatite (HA) as a bone graft. A Scanning microscopic image of HA crystal. B HA has been grafted into the rabbit's calvarial defect. New bone formation is observed around the vacant spots at 8 weeks postoperatively. Vacant spots are occupied by HA and dissolved during the decalcification procedure

of type I collagen. This type of material is mainly used as a scaffold for bone graft [15]. They are acellular collagen [15], gelatin [16], and silk fibroin [17]. Bio-degradable synthetic polymers are also used as a scaffold. They are polyL-lactic acid [18], polycaprolactone (PCL) [19], polyglycolic acid (PGA) [20], etc. They are known to accelerate the production of bone matrix protein. Accelerating the production of bone matrix protein is achieved by their degradation product (Fig. 1). As acellular collagen, gelatin, and silk fibroin are matrix proteins, they can be digested by proteolytic enzymes such as matrix metalloproteinases (MMPs) [21]. The degradation products are mainly peptides or amino acids. They may stimulate fibroblasts or osteoblasts to produce matrix proteins. Low-molecular weight silk fibroin accelerates type I collagen synthesis in osteoblast-like cells [22].

However, the scaffold cannot be used for repairing bony defects without any additive such as calcium-based material or osteo-inducers for angiogenesis and osteoinduction. In this case, the scaffold may be considered as a drug carrier. For optimal bone regeneration, controlled release from the scaffold is important [23]. When the scaffold is used solely, the bony defect may be mainly healed by fibrotic tissue. Because of these reasons, the calcium-based inorganic component has been frequently incorporated into the scaffold $[8,24]$.

Interestingly, BMP-2-soaked gelatin sponge has improved new bone formation [25]. In this case, gelatin sponge is used as a BMP-2 carrier for controlled release. Many types of osteo-inducers are hydrophilic and have low molecular weight. When this type of material is grafted into the bony defect without a proper carrier, it will be washed out. In humans, osteogenesis is started 3 or 4 weeks later event [26], and osteogenesis is maintained to 8 to 12 weeks later the event $[26,27]$. The therapeutic concentration of multi-functional materials should be maintained at least 3 weeks and ideally until 12 weeks. Unfortunately, most drug carrier releases osteo-inducer more than $80 \%$ within the first week. Thereafter, a high dose of osteo-inducer is loaded initially considering unwanted loss and may increase the chance of ectopic bone formation. Overloading of some osteo-inducers may show complications. For example, BMP is usually loaded to collagen at several tens to hundreds milligram levels [28]. The effective dosage of BMP at the cell level is nano-gram level. In clinical practice, BMP-2 has been approved for maxillofacial reconstruction in 2007 [29]. Some patients receiving BMP have shown excessive swelling and pain as complications [30].

\section{Osteo-inducer (materials for angiogenesis and osteoinduction) \\ $B M P$}

BMP is a representative material for osteo-inducer (Fig. 3). BMP is a family of transforming growth factor-beta [31]. There are several subtypes of BMPs. Among them, BMP-2, BMP-4, and BMP-7 have been considered as osteoinducers. BMP-2 has been approved by the Food and Drug Administration (FDA) in 2008 and used for clinical practice $[29,30]$. As a commercial product, BMP is provided as a recombinant protein. It can be produced either by Escherichia coli or Chinese hamster ovary $(\mathrm{CHO})$ cells. The difference between them is the presence of post-translational modification.

BMP-2 induces osteogenesis via upregulating runtrelated transcription factor-2 (Runx2) [32]. However, the cellular effect of BMP-2 is different from cellular types. BMP-2 can increase interleukins (ILs) and tumor necrosis factor- $\alpha$ (TNF- $\alpha)$ in immune cells [33]. BMP-2 administration to osteoclast can activate osteoclast via the nuclear factor- $\kappa B(N F-\kappa B)$ pathway [34]. BMP-2 may promote fat formation via activation of peroxisome proliferatoractivated receptor gamma (PPAR $\gamma$ ) signaling [35].

The FDA-approved dosage of BMP-2 for humans is $1.5 \mathrm{mg} / \mathrm{mL}$ [30]. The therapeutic effect of BMP-2 is dose-dependent [36]. As mentioned above, a high dosage 

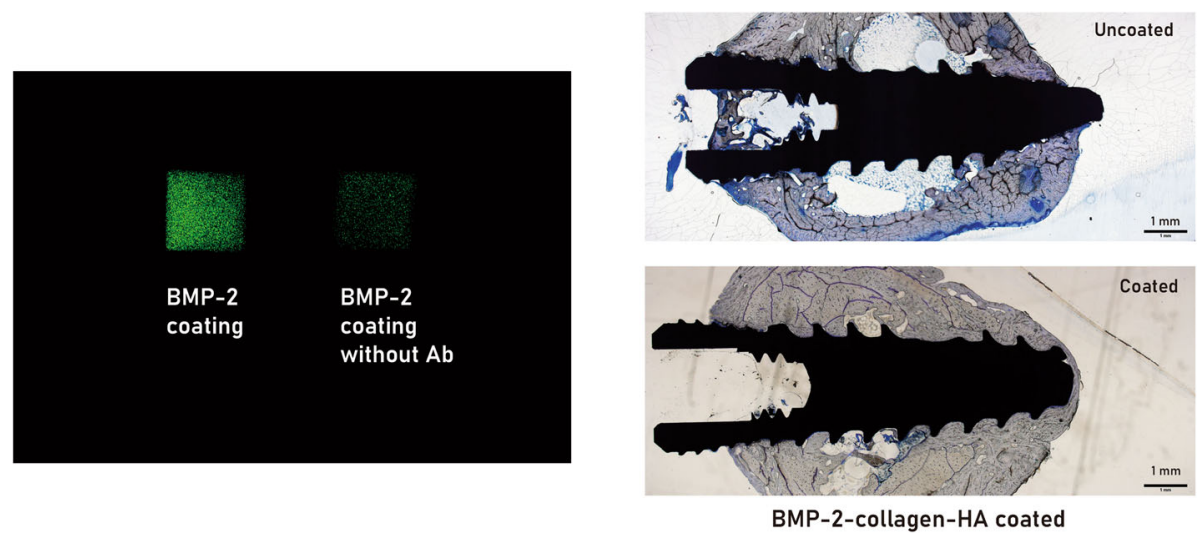

Fig. 3 Bone morphogenic protein-2 (BMP-2) has been coated on a hydroxyapatite (HA)-coated titanium surface. Successful incorporation is confirmed by immunofluorescence image (left). When applied anti-BMP-2 antibody with green fluorescence, BMP-2 coated plate showed high signal intensity. However, the same kind of plate without application of anti-BMP-2 antibody showed low signal intensity. BMP-2, collagen, and HA combination-coated dental implant shows better peri-implant bone formation compared to the uncoated dental implant (right)

of BMP-2 has been administered to get the clinical result, and this has been the main reason for complications [30]. Excessive BMP-2 may diffuse to the adjacent area and increase the chance of ectopic bone formation [37]. Inflammatory complications such as seroma are frequently observed at the 1 st week postoperatively [38, 39]. This type of inflammatory swelling can be life-threatening in the cervical area [40].

BMP is a required proper scaffold for successful bone regeneration. The scaffold for BMP can be used for other osteo-inducers. However, the optimal scaffold for each osteo-inducer is dependent on its physico-chemical feature. Most published papers used acellular collagen as a BMP scaffold. However, collagen is poor in BMP-2 retention capacity and may result in ectopic bone formation [30, 37]. Compared to collagen, hyaluronic acid and chitosan are better in retention capacity $[41,42]$. Synthetic materials such as poly lactic-co-glycolic acid (PLGA) [43] or PCL [44] are also used for BMP scaffolds. Unlike collagen, synthetic materials degrade by hydrolysis. Therefore, its degradation velocity is assumed more predictable compared to the natural matrix. However, this is a hypothesis and not enough evidence in the clinical practice. Unlike laboratory conditions, the velocity of hydrolysis may be unpredictable in the body.

As direct incorporation of BMP-2 into the scaffold has several problems as mentioned above, indirect methods such as incorporating BMP-2 inducer into the scaffold can be considered. Many materials inducing inflammation can increase the expression level of BMP-2 in the macrophage $[45,46]$. Lipopolysaccharide (LPS) is a bacterial endotoxin [47]. The administration of LPS on the periodontal ligament stem cells can increase the expression level of BMP-2 [47]. However, LPS induces too strong inflammation and may not be a proper agent for bone formation. Among foreign materials, silk sericin induces mild inflammation. Sericin can increase the expression level of BMP-2 in the macrophage [48]. The gelatin sponge incorporated with sericin can increase new bone formation compared to the gelatin sponge only graft $[48,49]$.

\section{PDGF and vascular endothelial growth factor (VEGF)}

Angiogenesis is a vital step for osteogenesis [30]. Medication-related jaw bone necrosis is a drug complication induced by impaired angiogenesis [50]. Diabetic bony lesion has also shown poor vascularity [49]. PDGF is rich in platelets. Concentrated PDGF can be produced by a simple centrifuge of whole blood [51]. They are platelet-rich plasma (PRP) or platelet-rich fibrin (PRF). PRP or PRF is a combination of growth factors and matrix protein [52]. Therefore, it can be used for smallsized defects without additional graft [53]. For the repair of large-sized defects, combination with calcium-based materials [54] or matrix protein $[51,53]$ has been tested and used.

As a recombinant protein, PDFG and VEGF have been tested for bone regeneration. VEGF only does not improve fracture healing, but VEGF plus BMP-2 enhances bone healing [55]. For the repair of tooth extraction socket, $0.3 \mathrm{mg} / \mathrm{mL}$ rhPDGF-BB plus calcium-based material is effective in clinical practice [56]. Compared to $\beta$-TCP alone, rhPDGF-BB plus $\beta$-TCP shows improved bone regeneration in the peri-implant defect [57].

\section{Macrophage polarizing agent}

Bone resident macrophage is called osteomac [58, 59]. Osteomac detects bone defects and orchestrated regeneration process [58]. During the acute 

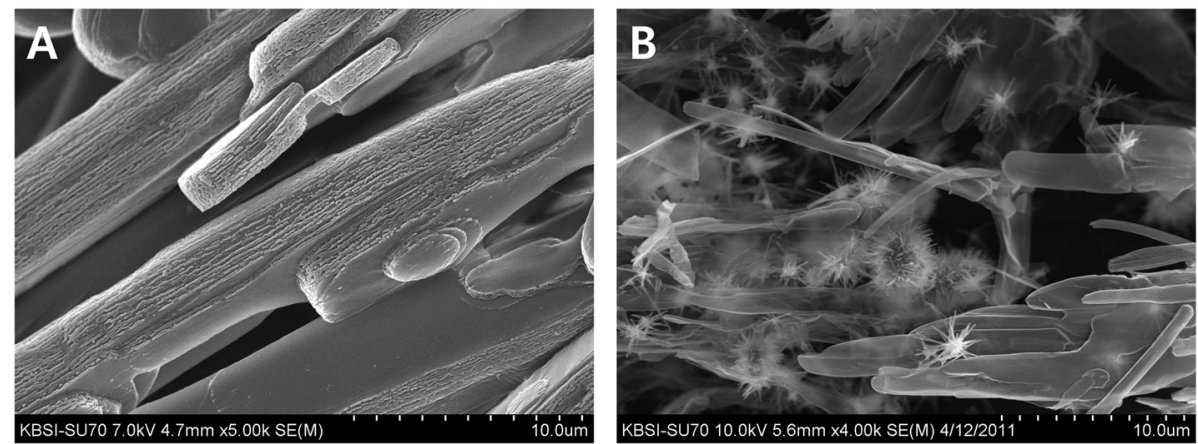

Fig. 4 Scanning microscopic image of the porcine scapula (A) and 4-hexylresorcinol incorporated into the scapula (B). 4-Hexylresorcinolincorporated scapula shows crystallization

inflammatory phase, osteomac recruits immune cells to defend microbial invasion and tissue destruction [59]. Osteomac invites fibroblasts and osteoblasts in the subsequent proliferating phase and remodeling phase [60]. When macrophage is classified as M0, M1, and M2, M1 type macrophage is prevalent in the acute inflammatory phase [7]. M2 type macrophage is prevalent in proliferating and remodeling phases [7]. Therefore, teaching macrophage to direct bone healing will be an interesting strategy for bone tissue engineering [7]. 4-Hexylresorcinol is identified as an M2 polarizing agent [61]. When 4-hexylresorcinol is incorporated into porcine scapula, dissolved calcium from the bone surface forms a crystal with 4hexylresorinol (Fig. 4). When HA incorporated with 4-hexylresorinol is grafted into the critical-sized defects, enhanced new bone formation is observed (Fig. 5). Silk fibroin combined with 4-hexylresorcinol reduces foreign body reactions induced by silk protein and increases new bone formation [8].

\section{Histone deacetylase (HDAC) inhibitor}

HDAC inhibitor is an emerging osteo-inducer. HDAC regulates bone remodeling. Accordingly, HDAC influences not only osteogenesis, but also osteoclastogenesis [62]. However, chemical or genetic blockade of HDAC results in osteogenic differentiation [63]. Therefore, the balance between bone formation and bone resorption may be tilted to bone formation by HDAC inhibition. HDAC inhibitor increases the expression of Sp1. Sp1 is a transcription factor for the transforming growth factor-beta (TGF- $\beta$ ) family such as TGF- $\beta 1$ and BMP-2/4. In addition, HDAC inhibitor increases the expression of Runx2. Runx2 is also a transcription factor, and its increased expression is associated with new bone formation [32]. Several papers have been published on this issue [64, 65]. HDAC inhibitors such as valproic acid (VPA) and trichostatin A (TSA) increase the expression level of BMP-2/4, osteocalcin, and Runx2 in dental pulp cells [66]. When a human mesenchymal stem cell is treated by

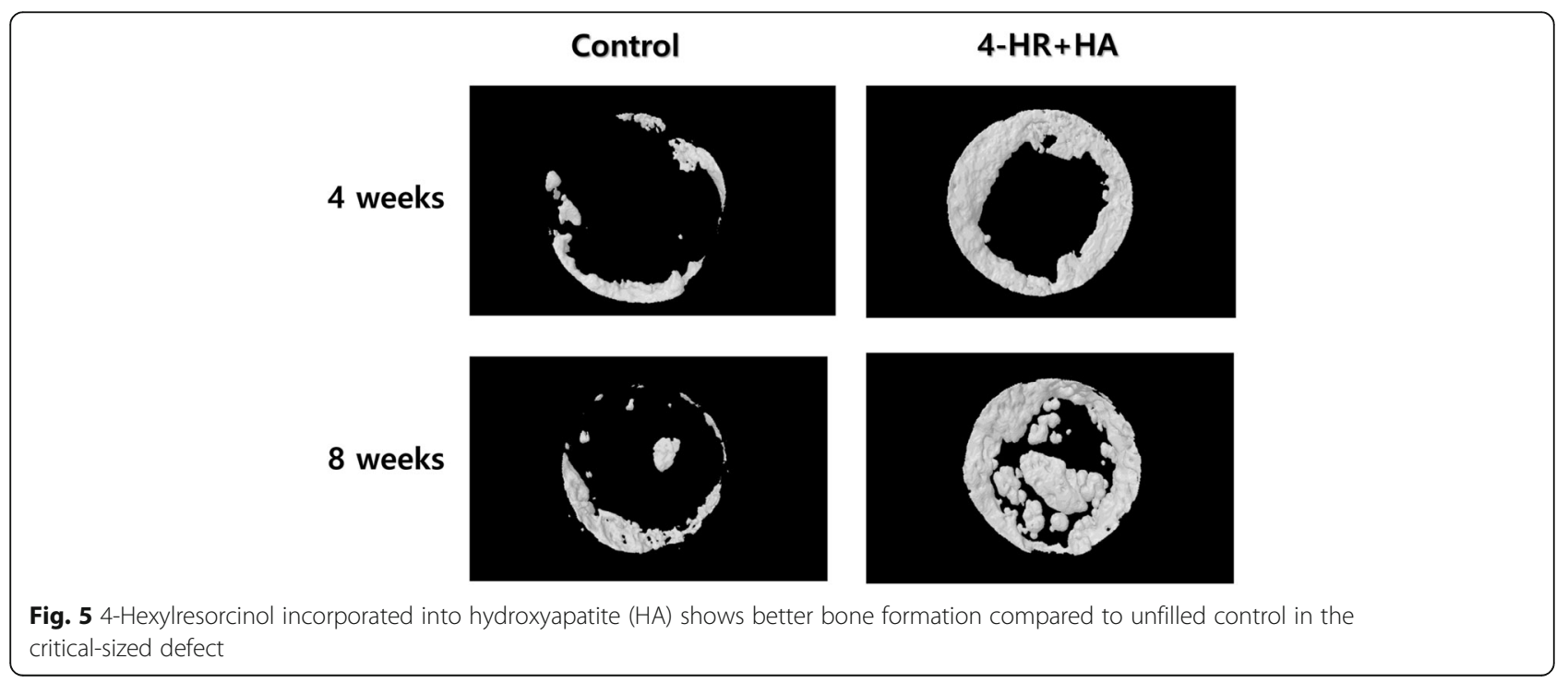


5-azacytidine plus TSA, the expression level of Runx2 is increased [67].

\section{Conclusion}

Crabs and insects have their hard tissues on the outside. The main role of this tissue is protection. This hard tissue is introduced into the body in the vertebrate. There are many advantages of this evolution. The main advantage may be easy repair. In this review, there have been many trials for helping bone repair. Although many kinds of bone substitutes are available, the ideal bone graft is still elusive.

\begin{abstract}
Abbreviations
BMP-2: Bone morphogenic protein-2; CHO: Chinese hamster ovary; FDA: Food and Drug Administration; HA: Hydroxyapatite; HDAC: Histone deacetylase; ILs: Interleukins; NF-kB: Nuclear factor-KB; PDGF: Platelet-derived growth factor; PLGA: Poly lactic-co-glycolic acid; PPARY: Proliferator-activated receptor gamma; PRF: Platelet-rich fibrin; PRP: Platelet-rich plasma; TGF$\beta$ : Transforming growth factor-beta; TNF-a: Tumor necrosis factor-a; TSA: Trichostatin A; VEGF: Vascular endothelial growth factor; VPA: Valproic acid; $\beta$-TCP: $\beta$-Tricalcium phosphate
\end{abstract}

\section{Acknowledgements}

This study was conducted with the support of the "Cooperative Research Program for Agriculture Science and Technology Development (Project no. PJ01562601)" Rural Development Administration, Republic of Korea.

\section{Author's contributions}

KSG solely wrote the original manuscript and edited figures. The author read and approved the final manuscript.

\section{Funding}

This study was conducted with the support of the "Cooperative Research Program for Agriculture Science and Technology Development (Project no. PJ01562601)" Rural Development Administration, Republic of Korea.

\section{Availability of data and materials}

Data sharing is not applicable to this article since no dataset was generated or analyzed during the current study.

\section{Declarations}

Ethics approval and consent to participate

Not applicable.

\section{Consent for publication}

Not applicable.

\section{Competing interests}

The author declares that he has no competing interests. KSG is an editorial board member of "Maxillofacial Plastic and Reconstructive Surgery."

\section{Received: 24 February 2021 Accepted: 22 February 2022}

\section{Published online: 02 March 2022}

\section{References}

1. Kang DW, Yun PY, Choi YH, Kim YK (2019) Sinus bone graft and simultaneous vertical ridge augmentation: case series study. Maxillofac Plast Reconstr Surg 41(1):36. https://doi.org/10.1186/s40902-019-0221-5

2. Onuma E, Azuma Y, Saito H, Tsunenari T, Watanabe T, Hirabayashi M, Sato K, Yamada-Okabe H, Ogata E (2005) Increased renal calcium reabsorption by parathyroid hormone-related protein is a causative factor in the development of humoral hypercalcemia of malignancy refractory to osteoclastic bone resorption inhibitors. Clin Cancer Res 11(11):4198-4203. https://doi.org/10.1158/1078-0432.CCR-04-2531
3. Son HJ, Kim JW, Kim SJ (2019) Pharmacoepidemiology and clinical characteristics of medication-related osteonecrosis of the jaw. Maxillofac Plast Reconstr Surg 41(1):26. https://doi.org/10.1186/s40902-019-0210-8

4. Grzibovskis M, Pilmane M, Urtane I (2010) Today's understanding about bone aging. Stomatologija. 12(4):99-104

5. Hilaire CS, Johnson A, Loseth C, Alipour H, Faunce N, Kaminski S, Sharma R (2020) Facial fractures and associated injuries in high- versus low-energy trauma: all are not created equal. Maxillofac Plast Reconstr Surg 42(1):22. https://doi.org/10.1186/s40902-020-00264-5

6. Salah M, Tayebi L, Moharamzadeh K, Naini FB (2020) Three-dimensional bioprinting and bone tissue engineering: technical innovations and potential applications in maxillofacial reconstructive surgery. Maxillofac Plast Reconstr Surg 42(1):18. https://doi.org/10.1186/s40902-020-00263-6

7. Kim SG (2020) Immunomodulation for maxillofacial reconstructive surgery. Maxillofac Plast Reconstr Surg 42(1):5. https://doi.org/10.1186/s40902-02000249-4

8. Kweon H, Kim SG, Choi JY (2014) Inhibition of foreign body giant cell formation by 4-hexylresorcinol through suppression of diacylglycerol kinase delta gene expression. Biomaterials 35(30):8576-8584. https://doi.org/10.101 6/j.biomaterials.2014.06.050

9. Osorio CC, Escobar LM, González MC, Gamboa LF, Chambrone L (2020) Evaluation of density, volume, height and rate of bone resorption of substitutes of autologous bone grafts for the repair of alveolar clefts in humans: a systematic review. Heliyon 6(9):e04646. https://doi.org/10.1016/j. heliyon.2020.e04646

10. Calcei JG, Rodeo SA (2019) Orthobiologics for bone healing. Clin Sports Med 38(1):79-95. https://doi.org/10.1016/j.csm.2018.08.005

11. Samee N, Geoffroy V, Marty C, Schiltz C, Vieux-Rochas M, Levi G, de Vernejoul MC (2008) Dlx5, a positive regulator of osteoblastogenesis, is essential for osteoblast-osteoclast coupling. Am J Pathol 173(3):773-780. https://doi.org/10.2353/ajpath.2008.080243

12. Lovy A, Molina AJ, Cerqueira FM, Trudeau K, Shirihai OS (2012) A faster, high resolution, mtPA-GFP-based mitochondrial fusion assay acquiring kinetic data of multiple cells in parallel using confocal microscopy. J Vis Exp 65(65): e3991. https://doi.org/10.3791/3991

13. Chang HY, Tuan WH, Lai PL (2021) Biphasic ceramic bone graft with biphasic degradation rates. Mater Sci Eng C Mater Biol Appl 118:111421. https://doi.org/10.1016/j.msec.2020.111421

14. Bouler JM, Pilet P, Gauthier O, Verron E (2017) Biphasic calcium phosphate ceramics for bone reconstruction: a review of biological response. Acta Biomater 53:1-12. https://doi.org/10.1016/j.actbio.2017.01.076

15. Kołodziejska B, Kaflak A, Kolmas J (2020) Biologically inspired collagen/apatite composite biomaterials for potential use in bone tissue regeneration-a review. Materials (Basel) 13(7):1748. https://doi.org/10.3390/ma13071748

16. Ranganathan S, Balagangadharan K, Selvamurugan N (2019) Chitosan and gelatin-based electrospun fibers for bone tissue engineering. Int J Biol Macromol 133:354-364. https://doi.org/10.1016/j.ijbiomac.2019.04.115

17. Sun W, Gregory DA, Tomeh MA, Zhao X (2021) Silk fibroin as a functional biomaterial for tissue engineering. Int J Mol Sci 22(3):1499. https://doi.org/1 0.3390/ijms22031499

18. Su X, Wang T, Guo S (2021) Applications of 3D printed bone tissue engineering scaffolds in the stem cell field. Regen Ther 16:63-72. https:// doi.org/10.1016/j.reth.2021.01.007

19. Rentsch B, Bernhardt R, Scharnweber D, Schneiders W, Rammelt S, Rentsch C (2012) Embroidered and surface coated polycaprolactone-co-lactide scaffolds: a potential graft for bone tissue engineering. Biomatter 2(3):158165. https://doi.org/10.4161/biom.21931

20. Gentile P, Chiono V, Tonda-Turo C, Ferreira AM, Ciardelli G (2011) Polymeric membranes for guided bone regeneration. Biotechnol J 6(10):1187-1197. https://doi.org/10.1002/biot.201100294

21. Jo YY, Kweon H, Kim DW, Kim MK, Kim SG, Kim JY, Chae WS, Hong SP, Park YH, Lee SY, Choi JY (2017) Accelerated biodegradation of silk sutures through matrix metalloproteinase activation by incorporating 4hexylresorcinol. Sci Rep 7(1):42441. https://doi.org/10.1038/srep42441

22. Kim JY, Choi JY, Jeong JH, Jang ES, Kim AS, Kim SG, Kwon HY, Jo YY, Yeo JH (2010) Low molecular weight silk fibroin increases alkaline phosphatase and type I collagen expression in MG63 cells. BMB Rep 43(1):52-56. https://doi. org/10.5483/BMBRep.2010.43.1.052

23. Oliveira ÉR, Nie L, Podstawczyk D, Allahbakhsh A, Ratnayake J, Brasil DL, Shavandi A (2021) Advances in growth factor delivery for bone tissue engineering. Int J Mol Sci 22(2):903. https://doi.org/10.3390/ijms22020903 
24. Jo YY, Kim SG, Kwon KJ, Kweon H, Chae WS, Yang WG, Lee EY, Seok H (2017) Silk fibroin-alginate-hydroxyapatite composite particles in bone tissue engineering applications in vivo. Int J Mol Sci 18(4):858. https://doi.org/10.33 90/ijms18040858

25. Kim SG, Jeong JH, Che X, Park YT, Lee SW, Jung ES, Choe S, Choi JY (2013) Reconstruction of radial bone defect using gelatin sponge and a BMP-2 combination graft. BMB Rep 46(6):328-333. https://doi.org/10.5483/ BMBRep.2013.46.6.231

26. Wang T, Zhang X, Bikle DD (2017) Osteogenic differentiation of periosteal cells during fracture healing. J Cell Physiol 232(5):913-921. https://doi.org/ 0.1002/jcp.25641

27. Oryan A, Alidadi S, Moshiri A, Bigham-Sadegh A (2014) Bone morphogenetic proteins: a powerful osteoinductive compound with nonnegligible side effects and limitations. Biofactors 40(5):459-481. https://doi. org/10.1002/biof.1177

28. Mesfin A, Buchowski JM, Zebala LP, Bakhsh WR, Aronson AB, Fogelson $J$, Hershman S, Kim HJ, Ahmad A, Bridwell KH (2013) High-dose rhBMP-2 for adults: major and minor complications: a study of 502 spine cases. J Bone Joint Surg Am 95(17):1546-1553. https://doi.org/1 0.2106/JBJS.L.01730

29. Rengachary SS (2002) Bone morphogenetic proteins: basic concepts. Neurosurg Focus 13(6):1-6. https://doi.org/10.3171/foc.2002.13.6.3

30. James AW, LaChaud G, Shen J, Asatrian G, Nguyen V, Zhang X, Ting K, Soo $C$ (2016) A review of the clinical side effects of bone morphogenetic protein-2. Tissue Eng Part B Rev 22(4):284-297. https://doi.org/10.1089/ten. teb.2015.0357

31. Bragdon B, Moseychuk O, Saldanha S, King D, Julian J, Nohe A (2011) Bone morphogenetic proteins: a critical review. Cell Signal 23(4):609-620. https://doi.org/10.1016/j.cellsig.2010.10.003

32. Lee KS, Kim HJ, Li QL, Chi XZ, Ueta C, Komori T, Wozney JM, Kim EG, Choi JY, Ryoo HM, Bae SC (2000) Runx2 is a common target of transforming growth factor beta1 and bone morphogenetic protein 2, and cooperation between Runx2 and Smad5 induces osteoblastspecific gene expression in the pluripotent mesenchymal precursor cell line C2C12. Mol Cell Biol 20(23): 8783-8792. https://doi.org/10.1128/MCB.20.23.8783-8792.2000

33. Suda T, Takahashi N, Udagawa N, Jimi E, Gillespie MT, Martin TJ (1999) Modulation of osteoclast differentiation and function by the new members of the tumor necrosis factor receptor and ligand families. Endocr Rev 20(3): 345-357. https://doi.org/10.1210/edrv.20.3.0367

34. Okamoto M, Murai J, Yoshikawa H, Tsumaki N (2006) Bone morphogenetic proteins in bone stimulate osteoclasts and osteoblasts during bone development. J Bone Miner Res 21(7):1022-1033. https://doi.org/10.1359/ jbmr.060411

35. Jeon MJ, Kim JA, Kwon SH, Kim SW, Park KS, Park SW, Kim SY, Shin CS (2003) Activation of peroxisome proliferator-activated receptor-gamma inhibits the Runx2-mediated transcription of osteocalcin in osteoblasts. J Biol Chem 278(26):23270-23277. https://doi.org/10.1074/jbc.M211610200

36. Govender S, Csimma C, Genant HK, Valentin-Opran A, Amit Y, Arbel R et al (2002) Recombinant human bone morphogenetic protein-2 for treatment of open tibial fractures: a prospective, controlled, randomized study of four hundred and fifty patients. J Bone Joint Surg Am 84(12):2123-2134. https://doi.org/10.2106/00004623-200212000-00001

37. Benglis D, Wang MY, Levi AD (2008) A comprehensive review of the safety profile of bone morphogenetic protein in spine surgery. Neurosurgery 62(5 Suppl 2):ONS423-ONS431. https://doi.org/10.1227/01.neu.0000326030.24220.d8

38. Robin BN, Chaput CD, Zeitouni S, Rahm MD, Zerris VA, Sampson HW (2010) Cytokine-mediated inflammatory reaction following posterior cervical decompression and fusion associated with recombinant human bone morphogenetic protein-2: a case study. Spine (Phila Pa 1976) 35(23):E1350E1354. https://doi.org/10.1097/BRS.0b013e3181e85756

39. Mindea SA, Shih P, Song JK (2009) Recombinant human bone morphogenetic protein-2-induced radiculitis in elective minimally invasive transforaminal lumbar interbody fusions: a series review. Spine (Phila Pa 1976) 34(14):1480-1484. https://doi.org/10.1097/BRS.0b013e3181a396a1

40. Smucker JD, Rhee JM, Singh K, Yoon ST, Heller JG (2006) Increased swelling complications associated with off-label usage of rhBMP-2 in the anterior cervical spine. Spine (Phila Pa 1976) 31(24):2813-2819. https://doi.org/10.1 097/01.brs.0000245863.52371.c2

41. Kim HD, Valentini RF (2002) Retention and activity of BMP-2 in hyaluronic acid-based scaffolds in vitro. J Biomed Mater Res 59(3):573-584. https://doi. org/10.1002/jbm.10011
42. Issa JP, do Nascimento C, Bentley MV, Del Bel EA, Iyomasa MM, Sebald W et al (2008) Bone repair in rat mandible by rhBMP-2 associated with two carriers. Micron 39(4):373-379. https://doi.org/10.1016/j.micron.2007. 03.008

43. Haidar ZS, Hamdy RC, Tabrizian M (2009) Delivery of recombinant bone morphogenetic proteins for bone regeneration and repair. Part B: delivery systems for BMPs in orthopaedic and craniofacial tissue engineering. Biotechnol Lett 31(12):1825-1835. https://doi.org/10.1007/s10529-009-0100-8

44. Kim KJ, Choi MS, Shim JH, Rhie JW (2019) Bone morphogenetic protein 2conjugated silica particles enhanced early osteogenic differentiation of adipose stem cells on the polycaprolactone scaffold. Tissue Eng Regen Med 16(4):395-403. https://doi.org/10.1007/s13770-019-00195-x

45. Song R, Fullerton DA, Ao L, Zheng D, Zhao KS, Meng X (2015) BMP-2 and TGF- $\beta 1$ mediate biglycan-induced pro-osteogenic reprogramming in aortic valve interstitial cells. J Mol Med (Berl) 93(4):403-412. https://doi.org/10.1 007/s00109-014-1229-Z

46. Su X, Ao L, Shi Y, Johnson TR, Fullerton DA, Meng X (2011) Oxidized low density lipoprotein induces bone morphogenetic protein-2 in coronary artery endothelial cells via Toll-like receptors 2 and 4. J Biol Chem 286(14): 12213-12220. https://doi.org/10.1074/jbc.M110.214619

47. Fu Z, Wang X, Li B, Tang Y (2021) Fraxinellone alleviates inflammation and promotes osteogenic differentiation in lipopolysaccharide-stimulated periodontal ligament stem cells by regulating the bone morphogenetic protein 2/Smad pathway. Arch Oral Biol 121:104927. https://doi.org/10.1016/ j.archoralbio.2020.104927

48. Jo YY, Kweon H, Kim DW, Baek K, Chae WS, Kang YJ, Oh JH, Kim SG, Garagiola U (2021) Silk sericin application increases bone morphogenic protein-2/4 expression via a toll-like receptor-mediated pathway. Int J Biol Macromol 190:607-617. https://doi.org/10.1016/j.ijbiomac.2021.09.021

49. Hong KDG, Kang YJ, Oh JH, Kim SG, Park YW, Jo YY, Kweon HY, Rotaru H (2021) The effect of sericin on bone regeneration in a streptozotocininduced type I diabetes animal model. Appl Sci 11(4):1369. https://doi.org/1 0.3390/app11041369

50. Choi JY, Kim HJ, Lee YC, Cho BO, Seong HS, Cho M, Kim SG (2007) Inhibition of bone healing by pamidronate in calvarial bony defects. Oral Surg Oral Med Oral Pathol Oral Radiol Endod 103(3):321-328. https://doi. org/10.1016/j.tripleo.2006.06.057

51. Jang ES, Park JW, Kweon H, Lee KG, Kang SW, Baek DH, Choi JY, Kim SG (2010) Restoration of peri-implant defects in immediate implant installations by Choukroun platelet-rich fibrin and silk fibroin powder combination graft. Oral Surg Oral Med Oral Pathol Oral Radiol Endod 109(6):831-836. https:// doi.org/10.1016/j.tripleo.2009.10.038

52. Kobayashi E, Flückiger L, Fujioka-Kobayashi M, Sawada K, Sculean A, Schaller B, Miron RJ (2016) Comparative release of growth factors from PRP, PRF, and advanced-PRF. Clin Oral Investig 20(9):2353-2360. https://doi.org/10.1 007/s00784-016-1719-1

53. Melville JC, Mañón VA, Blackburn C, Young S (2019) Current methods of maxillofacial tissue engineering. Oral Maxillofac Surg Clin North Am 31(4): 579-591. https://doi.org/10.1016/j.coms.2019.07.003

54. Zhong D, Wang CG, Yin K, Liao Q, Zhou X, Liu AS et al (2014) In vivo ossification of a scaffold combining $\beta$-tricalcium phosphate and platelet-rich plasma. Exp Ther Med 8(5):1381-1388. https://doi.org/10.3892/etm.2014.1969

55. Patel ZS, Young S, Tabata Y, Jansen JA, Wong ME, Mikos AG (2008) Dual delivery of an angiogenic and an osteogenic growth factor for bone regeneration in a critical size defect model. Bone 43(5):931-940. https://doi. org/10.1016/j.bone.2008.06.019

56. Li F, Yu F, Liao X, Wu C, Wang Y, Li C, Lou F, Li B, Yin B, Wang C, Ye L (2019) Efficacy of recombinant human BMP2 and PDGF-BB in orofacial bone regeneration: a systematic review and meta-analysis. Sci Rep 9(1):8073. https://doi.org/10.1038/s41598-019-44368-z

57. Choo T, Marino V, Bartold PM (2013) Effect of PDGF-BB and beta-tricalcium phosphate ( $\beta$-TCP) on bone formation around dental implants: a pilot study in sheep. Clin Oral Implants Res 24(2):158-166. https://doi.org/10.1111/j.1 600-0501.2011.02345x

58. Miron RJ, Bosshardt DD (2016) OsteoMacs: key players around bone biomaterials. Biomaterials 82:1-19. https://doi.org/10.1016/j.biomaterials.201 5.12 .017

59. Batoon L, Millard SM, Wullschleger ME, Preda C, Wu AC, Kaur S et al (2019) CD169 ${ }^{+}$macrophages are critical for osteoblast maintenance and promote intramembranous and endochondral ossification during bone repair. Biomaterials 196:51-66. https://doi.org/10.1016/j.biomaterials.2017.10.033 
60. Bozec A, Soulat D (2017) Latest perspectives on macrophages in bone homeostasis. Pflugers Arch 469(3-4):517-525. https://doi.org/10.1007/s00424017-1952-8

61. Jo YY, Kim DW, Choi JY, Kim SG (2019) 4-Hexylresorcinol and silk sericin increase the expression of vascular endothelial growth factor via different pathways. Sci Rep 9(1):3448. https://doi.org/10.1038/s41598-019-40027-5

62. Huynh NC, Everts V, Ampornaramveth RS (2017) Histone deacetylases and their roles in mineralized tissue regeneration. Bone Rep 7:33-40. https://doi. org/10.1016/j.bonr.2017.08.001

63. Maroni P, Brini AT, Arrigoni E, de Girolamo L, Niada S, Matteucci E, Bendinelli P, Desiderio MA (2012) Chemical and genetic blockade of HDACs enhances osteogenic differentiation of human adipose tissue-derived stem cells by oppositely affecting osteogenic and adipogenic transcription factors. Biochem Biophys Res Commun 428(2):271-277. https://doi.org/10.1016/j. bbrc.2012.10.044

64. Hu X, Zhang X, Dai L, Zhu J, Jia Z, Wang W, Zhou C, Ao Y (2013) Histone deacetylase inhibitor trichostatin A promotes the osteogenic differentiation of rat adipose-derived stem cells by altering the epigenetic modifications on Runx2 promoter in a BMP signaling-dependent manner. Stem Cells Dev 22(2):248-255. https://doi.org/10.1089/scd.2012.0105

65. Zhang P, Tao F, Li Q, Wu S, Fu B, Liu P (2019) 5-Azacytidine and trichostatin A enhance the osteogenic differentiation of bone marrow mesenchymal stem cells isolated from steroid-induced avascular necrosis of the femoral head in rabbit. J Biosci 44(4):87. https://doi.org/10.1007/s12038-019-9901-7

66. Sultana S, Uehara O, Yoshida K, Saito T, Abiko Y (2021) The histone deacetylase inhibitor, entinostat (MS-275), induces the odontogenic differentiation of an odontoblast-like cell line in the absence of an osteoblast mineralization medium. Odontology doi 109(3):661-671. https://doi.org/10.1007/s10266-020-00588-8

67. Kim HJ, Kwon YR, Bae YJ, Kim YJ (2016) Enhancement of human mesenchymal stem cell differentiation by combination treatment with 5-azacytidine and trichostatin A. Biotechnol Lett 38(1):167-174. https://doi.org/10.1007/s10529-015-1949-3

\section{Publisher's Note}

Springer Nature remains neutral with regard to jurisdictional claims in published maps and institutional affiliations.

\section{Submit your manuscript to a SpringerOpen ${ }^{\circ}$ journal and benefit from:}

- Convenient online submission

- Rigorous peer review

- Open access: articles freely available online

- High visibility within the field

- Retaining the copyright to your article

Submit your next manuscript at $\boldsymbol{\nabla}$ springeropen.com 